\title{
A Study on the Implementation of Students' Classroom Oral Interaction in Sire Secondary School EFL Class: Grade 10 in Focus
}

\author{
Zeleke Teshome Lucha* and Alemtsehay Berhanu
}

\author{
Institute of Language Studies and Journalism, Department of Language Studies and Literature, \\ Wollega University, Post Box No: 395, Nekemte, Ethiopia
}

\begin{tabular}{|c|c|}
\hline Abstract & Article Information \\
\hline $\begin{array}{l}\text { The purpose of this paper was to study students' classroom interaction in EFL speaking } \\
\text { classroom in East Wollega zone, Sire Secondary School. To this effect, a descriptive method of } \\
\text { research design was found to be the best fit for this study. The data were collected using } \\
\text { random sampling technique from } 182 \text { students and availability sampling from } 5 \text { teachers of the } \\
\text { school. To gather data three instruments were used, namely: Classroom observation, interview } \\
\text { for teachers, and questionnaire for students. The data were collected and analyzed both } \\
\text { quantitatively and qualitatively. The findings of the study revealed that English language } \\
\text { classroom oral interaction was not properly implemented in the stated grade level, and teachers } \\
\text { and students did not perform the roles expected of them astoundingly. Furthermore, lack of } \\
\text { students' interest to orally interact, lack of English teacher's commitment to create conducive } \\
\text { atmosphere for their learners to freely interact, teachers' not budgeting enough time for } \\
\text { students' interaction, large class size to moderately keep an eye on oral interaction and } \\
\text { students' insufficient in English language background at lower schooling are found to be the } \\
\text { core setbacks for effective implementation of oral interaction. Hence, it was recommended that } \\
\text { teachers should make their maximum effort by encouraging students whose English oral } \\
\text { proficient becomes below the required grade level to interact in language classroom. EFL } \\
\text { teachers should also be aware and implement that their friendly approach to their students } \\
\text { plays its own role in boosting up students' interaction. Therefore, teachers ought to approach } \\
\text { their students in providing professional support during classroom interaction. Furthermore, } \\
\text { teachers should provide maximum opportunity to students to participate in oral interaction so } \\
\text { that they could play the roles expected of them. Finally, the school community and other } \\
\text { concerned body should also create favorable classroom environment to minimize the problems } \\
\text { encountered and to maximize the implementation of students' oral interaction in EFL classroom. } \\
\text { copyright@2015 STAR Journal, Wollega University. All Rights Reserved. }\end{array}$ & $\begin{array}{l}\text { Received : 04-04-2015 } \\
\text { Revised : 15-06-2015 } \\
\text { Accepted : 23-06-2015 } \\
\text { Keywords: } \\
\text { Interaction } \\
\text { Active learning } \\
\text { Implementation } \\
\text { Oral interaction }\end{array}$ \\
\hline
\end{tabular}

\section{INTRODUCTION}

English has been widely used in many areas such as politics, economics, tourism, electronics, telecommunication, culture and science and technology. It is not only a means but also a key to access the latest development in science and technology. Therefore, it is becoming compulsory for many Ethiopians to have a good command of English to satisfy the growing needs of the language in the country.

Currently, in the context of Ethiopian, English is used as a means of communication in international and local NGO's, federal and regional legislative documents, import and export oriented business organizations, government and non-government media of printed and electronic types, entertainments (e.g., music and movies), and business promotion and advertisement activities. Thus, English has become a key to unlock business of government and NGOs in the country. This undeniable fact calls language researchers to strive for the betterment of the quality of English language teaching in the country.
Thus, the quality of the teaching and learning of English should be given due emphasis.

The increasing requirement of the language at all levels has brought a need for a new approach which enables students learn how the language system is used for communication. Thus, the nature of classroom interaction by far and large, could take a more important role in the general running of foreign language classes from entry to subject completion.

The main aim of learning language is to use it for communication purposes in its actual class setting in which classroom interaction is a key to achieve this. Basically, oral interaction is the collaborative exchange of thoughts, feelings or ideas between two or more people, leading to a mutual effect on each other. As Rivers (1987: 29) puts, "...through [oral] interaction, students can increase their language store as they listen to or read authentic tasks or dialogue journals". 
Zeleke Teshome Lucha \& Alemtsehay Berhanu

It is also undeniable fact that classroom interaction enables students to develop their speaking skills that makes it mandatory to encourage them interact actively in EFL classroom.

However, these days there is a great problem on students' oral interaction in EFL classroom. According to Bygate (1987), one of the basic problems of foreign language teaching is preparing learners to be able to use the language interactively. These days, the problem is likely to be serious at all levels in Ethiopian schools. It is an intimidating challenge for learners to use the language even to express themselves appropriately and efficiently. In interaction, he adds "students can use all they possess of the language, all they have learned or casually observed in real life exchanges ..." (p. 4-5).

In Ethiopian educational system, students are exposed for 12 years to English language before they join institution of higher education. Put differently, English is given as a compulsory subject starting from grade one to high school and preparatory classes. One of the main reasons why students learn the subject is that the English language is a medium of instruction starting from grade nine. In addition to this, English language is being studied as a major subject by teachers of English at tertiary levels that is in the universities and colleges. Therefore, teachers of English who are assigned to teach English are expected to explain, communicate with students, and question them effectively and respond fully to their questions using the English language (MOE, 2003, p.41).

This idea implies that there should be useful oral interaction between English teachers and their students in EFL classroom. In this respect, the role of English language is to foster classroom interaction to develop students' speaking abilities. Despite such broad coverage allotted to English language as subject and medium of instruction in curriculum, the students' proficiency in the language seems not adequate enough to meet the demands of their classroom. In support of this point, Tamane, (2000) in his study, depicts the students' performance in English language skills as follows:

Despite the importance of the English language in individual student's life both in and after school and in the country's overall development endeavors, there is one general dissatisfaction that is invariably expressed by English teachers at different levels of the educational system; students' performance in English language skill is generally less than adequate to meet the demands that their class-room level requires of them(P.1).

Therefore, this finding directly or indirectly reveals that there is an acute problem which requires further investigation.

In different classroom discourses, it is not uncommon to read that classroom interaction enables students to develop their speaking skills. However, even though Ethiopian students are exposed to the English language starting from grade 1, and on top of this, the language also used as a medium of instruction starting from grade nine, the researchers' informal experiences indicate that most students fail to communicate in English language. As a result, the researchers were motivated to investigate the implementation of students' classroom interaction.
Sci. Technol. Arts Res. J., April-June 2015, 4(2): 294-301

However, there are plenty of locally conducted researches with regard to classroom interaction which show that students after learning English from elementary to secondary schools master only the language systems. That is, they are not provided with opportunities to practice the different ways of interaction using the spoken language in EFL class. For example, research study conducted by Sisay (1999), on "Classroom Interaction and Its Influence on the Development of Students' Speaking Skill in English at grade 11 Levels in Government Schools" looks at the classroom interaction and its influence on the development of students' speaking skills in English. His finding shows that EFL teacher's unbalanced approach between accuracy and fluency can affect the classroom interaction negatively and this has an influence on the development of students' speaking skills. It gives emphasis only to grammar exercise; and focuses always on accuracy and teacher controlled methods which inhabit students from developing their speaking skills.

On the other hand, in an EFL speaking class, Melaku (2005), studied on implications of classroom interaction and his finding revealed that oral interaction is not to the demanded goal that promotes oral communicative skills. Most students do not understand the proper role expected of them. Additionally, Ayele's (2008), study revealed that there is a mismatch between what EFL classroom oral interactions theory claims and what is actually practiced in the classroom. Not only this, Meseret's (2007), research finding shows that classroom interaction in teaching speaking is not successfully implemented.

As the researchers tried to mention above, some research studies have been conducted in the English class in EFL speaking lessons by local researchers. But these studies focus on the implementation of students' classroom interaction in EFL classroom and to fill the gap that was not seen by either grade level or by researchers' prospective. Basically, it differs in the variables selected where these were not mentioned by other researchers in the way the present researchers would try to study. As mentioned above almost all studies revealed that student's oral interaction in EFL classroom is less than adequate to meet the demands that their classroom levels require of them. That is the issue that inspired the present study. The researchers' teaching experiences in governmental schools and the different studies done on similar issues have convinced the researchers to investigate the study. Even if, different researches were conducted in different places on the topic, no study was conducted in relation to the implementation of students' classroom interaction in EFL speaking class in Sibu Sire district. The researchers believe that the findings obtained in higher education and other places may not work for the district context because people of the district may not have the opportunity to get those researches conducted in different places to use their findings. Besides, as the research finding have relation with its context or area of the study, problem on implementation of students classroom interaction in one area may not exactly the same with other area, so the setting factor is also another reason which makes this research different. As a result of this, the present researchers triggered to conduct a study on students' classroom interaction in EFL speaking class.

The objective of the study is to investigate the implementation of students' oral interaction in EFL 
speaking classroom in one government secondary school in East Wollega Zone, Sibu Sire District, (Grade 10 in focus). The study aims at studying the implementation of students' classroom interaction. Accordingly, the results of this study may have the following significances. It may enhance EFL teachers' awareness in doing on the interaction in EFL classroom. It may create conducive environment for students on interaction in EFL classroom by indicating area of challenges and recommending its solution. It may contribute to improve interaction in EFL classroom. It may also serve as supporting document for further study.

\section{MATERIALS AND METHODS}

\section{Research Design}

The study was conducted in East Wollega, Sire Secondary School Grade 10 EFL Classes. A descriptive design was used to conduct the study which enabled the researchers to describe events, and to define clearly students' classroom oral interaction in EFL speaking classroom of grade10.

\section{Sample of the Study}

With regards to sample selection, the subjects of the study were randomly selected 182 grade 10 students from the sampled school based on the total population of the school. The researchers used simple random sampling as it involves picking a certain number of participants out of the total of possible participants in the sampling frame. Moreover, 5 English language teachers were included in the study by availability or comprehensive sampling techniques since a number of teachers in the school are manageable.

\section{Data Collection Instruments}

To gather data for the study, three different instruments were employed. These were classroom observation, interviews and questionnaires, In brief, the necessary information about the study was obtained by observing speaking lessons, interviewing teachers and distributing questionnaire to students.

To obtain the required information, classroom observation session was conducted in five sections of the selected school. The selection of the sections was based on the willingness of the teachers to be observed who were currently teaching English language in grade 10. Each class was observed three times in different speaking lessons. The observation sessions was conducted on the basis of structured observation checklist which was adapted from FIAC (Flanders Interaction Analysis Categories, by Moskowitz, 1978). Consequently, students' participation was assessed while they were doing the interaction activities based on the revised items in the checklist.

For this study, semi-structured interview was employed in a systematic and consistent order. Interview was felt to be suitable for the study for two reasons. First, the study was descriptive in which interview was employed to secure relevant data. Second, the participants who were interviewed were manageable which made an interview appropriate (Nunan, 1992). Generally, a semi-structured interview was set to collect information from five teachers who were selected by availability or comprehensive sampling. It was conducted immediately after classroom observation was over by the researchers and co-interviewer once in the school compound.

The questionnaire was given to 182 of the total students of the school. The sets of questionnaire item were designed for students, with five scales ranging from 'strongly agree' to 'strongly disagree' in order. The items in the questionnaires were all close ended.

\section{Data Collection Procedures}

In the course of collecting data for this study, all the necessary procedures were followed. First, the researchers were strengthening relationship with the respondents by enlightening the objective of the study to each respondent before data collection period targeting to exploit full information from them.

The participants were informed that their participation in this study was strictly voluntary and any information obtain in connection with this study that was identified with them remain confidential. Furthermore, it was highlighted that there was no cost to the participants for participation in this study. Finally, it was explained to the participants that their decision whether or not to participate could not affect their future relation with the investigators.

Basically, the teachers were asked that the researchers were going to observe them three times at different periods of sessions while they teach. This was to make them aware that the observation is based on their interest. In addition, the researchers oriented them that there was an interview at the same time and place with some participants. While the students were filling the questionnaire, the researchers were clearing up any possible misunderstanding that the student-participants faced even by translating into their mother tongue orally when needed.

\section{Methods of Data Analysis}

First, the number of the student-participants was changed into percentage to know how many of them responded to specific items from the total population. Then, qualitative description was given to each percentage by transcribing through words. Concerning the analysis of data obtained via classroom observation and interviews, it was analyzed qualitatively using words and quotes taken from the participants' statements.

\section{RESULTS AND DISCUSSION}

\section{Teachers Help during Students' Interaction}

In this section, presentation and analysis of data which were obtained through questionnaire, observation and interview regarding how teachers provide help for their students to interact using the target language in the classroom are discussed.

Table 1 summarizes the responses of students to indicate how their teachers help them during oral interaction in EFL classrooms.

To begin with item number 1 which says "Our English teacher often asks oral question in the classroom", it is indicated in the table that $2.7 \%$ of the students responded that they do "agree" that English language teachers regularly raise oral questions that initiate them to take part in the interaction activities. But, $76.3 \%$ of the students responded that they "disagree" and $20.8 \%$ of them replied that they strongly disagree. Thus, the data confirm that 
the majority of language teachers were not trying their level best to help their students engage in oral interaction by asking oral questions as believing that students are not interested to take part in oral interaction. Furthermore, the data obtained from the interviews and classroom observation indicate that teachers are slightly reluctant in asking questions as their students are not in a position to actively participate when the teacher asks oral interaction. During the interview, the EFL teachers specifically reacted that they don't want to waste their time by asking oral questions.

Table 1: How teachers help students' during their oral interaction

\begin{tabular}{|c|c|c|c|c|c|c|c|c|c|c|c|}
\hline \multirow{2}{*}{ No } & \multirow{2}{*}{ Statement/s } & \multicolumn{2}{|c|}{1} & \multicolumn{2}{|c|}{2} & \multicolumn{2}{|c|}{3} & \multicolumn{2}{|c|}{4} & \multicolumn{2}{|c|}{5} \\
\hline & & No & $\%$ & No & $\%$ & No & $\%$ & No & $\%$ & No & $\%$ \\
\hline 1. & Our English teacher often asks oral question & - & - & 5 & 2.7 & 139 & 76.3 & 38 & 20.8 & - & - \\
\hline 2. & $\begin{array}{l}\text { Our teachers' asks open-ended questions to help us to } \\
\text { speak a lot. }\end{array}$ & 10 & 5.4 & 12 & 6.5 & 148 & 81.3 & 12 & 6.5 & - & - \\
\hline 3. & $\begin{array}{l}\text { I participate in oral interaction activities when the } \\
\text { teachers warm and friendly }\end{array}$ & 2 & 1 & 8 & 4.3 & 132 & 72.5 & 40 & 22 & - & - \\
\hline 4. & $\begin{array}{l}\text { I feel that my English teacher motivates me during } \\
\text { implementing oral interaction activities. }\end{array}$ & 38 & 20.8 & 38 & 20.8 & 66 & 36.2 & 40 & 22 & - & - \\
\hline 5. & $\begin{array}{l}\text { My English teacher focuses only on active students } \\
\text { when implementing oral interaction activities. }\end{array}$ & 123 & 67.5 & 39 & 21.4 & 8 & 4.3 & 12 & 6.5 & - & - \\
\hline 6. & $\begin{array}{l}\text { My English teacher gives clear instruction for us to } \\
\text { understand. }\end{array}$ & - & - & 38 & 20.8 & 74 & 40.6 & 70 & 38.4 & - & - \\
\hline 7. & $\begin{array}{l}\text { My English teacher organizes us well to perform } \\
\text { different oral interaction activities. }\end{array}$ & - & - & 38 & 20.8 & 80 & 44 & 50 & 27.4 & 14 & 7.6 \\
\hline
\end{tabular}

Keys: 1 =strongly agree, 2 = Agree, $3=$ Disagree 4 = strongly disagree $5=$ Have no idea

To consolidate the issue raised in item 1 , it is raised in item 2 that 'Our teachers' ask open-ended questions to help us to speak a lot". Accordingly, $81.3 \%$ of the students replied that they disagreed that no open-ended questions that help them during oral interaction would be asked by their English teachers, whereas $6.5 \%$ of them strongly disagreed on the idea. In addition to the above mentioned students' data, the observation result also showed that teachers don't like asking open-ended question because of their students' less interest. Therefore, from the data, it is possible to infer that teachers are not in a position to instigate their students by asking oral questions as they simply predict that students will not participate even if the teachers ask the question.

The other similar point which is raised under item 3 says "I participate in oral interaction activities when the teachers are warm and friendly". Thus, as depicted in the above table, $72.5 \%$ of the students responded that they disagree to this item and $22 \%$ of them strongly disagree but $4.3 \%$ agree and $1 \%$ strongly agrees. Indeed, the observation and interview results also revealed that even if students don't have interest to participate in oral interaction, they sometimes take part when their teachers are responsive and welcoming.

For example, during the interviews made with T1 and T2, they replied that students sometimes take part when teachers are approachable and hospitable for them. However, other teacher-respondents i.e. T3, T4 and T5 replied that students are not willing to take part even whether they are open for them. From this data, it can be possible to notice that being warm and friendly plays its own role in oral interaction class but not at all occasions.

In item 4, the issue of motivation such as "I feel that my English teacher motivates me during the implementation of oral interaction activities" was raised. Thus, from all student- respondents, $20.8 \%$ of them responded that they strongly agree and 20.8 of them merely agree. In contrary to this, $36.2 \%$ of the students disagree and $22 \%$ of them strongly disagree. However, both the results of the observation and the interviews with the students point out that teachers' motivation is not as demanded. Put differently, the teachers were not as such enthusiastic in motivating their students.

Regarding item 5 which says, "My English teacher focuses only on active students when implementing oral interaction", $67.5 \%$ of the students responded that they strongly agree and $21.4 \%$ of them agree that English teachers focus simply on active students' oral participation rather than giving chance for all students. Similarly, the data from the observation sessions and the interview result revealed that teachers frequently focus on active students because other students don't want to interact by the target language in the classroom. During interviews conducted with T1andT2, they replied that they give equal chances for all students to participate during oral interaction activities. However, students don't participate equally as only active students were given special attention by their language teachers during oral participation.

Nevertheless, T3, T4 and T5 responded that they don't waste their time to give equal chance for all students to participate because it is known that only active students participate during oral interaction. So, they replied that they give chances for voluntary students. The data show that teachers are not giving equal emphasis for all students. On the other hand, it is also possible to infer that the EFL teachers don't allow students to learn among themselves to develop their oral skills.

Concerning item 6 which goes saying, "My English teacher gives clear instruction for us to understand", $40.6 \%$ of the students responded that they disagree on getting clear instruction, and $38.4 \%$ of the students responded that they strongly disagree. Similarly, the observation result revealed that teachers rarely make effort to give instruction in order for students to be aware of what they perform. This data show that teachers are less committed in providing help for their students during oral interaction by the target language. The other theme raised under item 7 reads, "My English teacher organizes us to well perform different oral interaction activities" in 
Zeleke Teshome Lucha \& Alemtsehay Berhanu

which $44 \%$ of the students showed that they disagree to the language teachers organizing role and $27.4 \%$ of the students responded that they strongly disagree. Similarly, the observation result showed that teachers rarely organize students well to perform different oral interactional activities. Furthermore, the interview result revealed that English language teachers of the selected school don't organize well because large class size and fixed sitting arrangement. For example, T1 replied that he tried to organize learners even if there are problems. But, other teacher-respondents such as T2, T3, T4 and T5 responded that they don't organize students well to perform different interaction activities because of shortage of time and others.

Generally, the data obtained from students' questionnaires, observation and interview indicated that
Sci. Technol. Arts Res. J., April-June 2015, 4(2): 294-301

teachers are not playing their required roles in helping students during oral interaction. Even though the EFL teachers may have their own justifiable reasons for not doing what is expected of them, a deliberate reluctance was also seen from their sides by taking for granted that the students are always passive and giving the chance only for voluntary students instead of creating conducive environment for collaborative learning.

\section{Challenges that Students Face during Oral Interaction in EFL Classes}

In the forthcoming section, data which were collected from students' questionnaires, classroom observations and interview regarding the challenges that students face during oral interaction are presented and analyzed. Notice that the keys used to represent the scale in table 2 are similar with that of table 1 above.

Table 2: Challenges that student face during oral interaction in EFL classroom

\begin{tabular}{|c|c|c|c|c|c|c|c|c|c|c|c|}
\hline \multirow{2}{*}{ No } & \multirow{2}{*}{ Statement/s } & \multicolumn{2}{|c|}{1} & \multicolumn{2}{|c|}{2} & \multicolumn{2}{|c|}{3} & \multicolumn{2}{|c|}{4} & \multicolumn{2}{|c|}{5} \\
\hline & & No & $\%$ & No & $\%$ & No & $\%$ & No & $\%$ & No & $\%$ \\
\hline 1. & $\begin{array}{l}\text { I often feel shy and fearful to speak in English } \\
\text { even with my classmates. }\end{array}$ & 92 & 50.5 & 60 & 32.9 & 8 & 4.3 & 12 & 6.5 & 10 & 5.4 \\
\hline 2. & $\begin{array}{l}\text { I prefer grammar and vocabulary practice than oral } \\
\text { interaction }\end{array}$ & 102 & 56 & 50 & 27.4 & 10 & 5.4 & 12 & 6.5 & 8 & 4.3 \\
\hline 3. & $\begin{array}{l}\text { A major portion of class time is taken up by } \\
\text { teachers talk. } \\
\text { I feel discouraged to participate when the teacher }\end{array}$ & 132 & 72.5 & 50 & 27.4 & - & - & - & - & - & - \\
\hline 4. & $\begin{array}{l}\text { interrupts to correct our oral errors while } \\
\text { interacting. }\end{array}$ & 122 & 67 & 20 & 11 & 10 & 5.4 & 20 & 11 & - & - \\
\hline 5. & $\begin{array}{l}\text { The time given to do oral interaction activities is } \\
\text { insufficient. }\end{array}$ & 10 & 5.4 & 148 & 81.3 & 12 & 6.5 & 12 & 6.5 & - & - \\
\hline 6. & $\begin{array}{l}\text { I am not willing to talk freely in the class as I was } \\
\text { not accustomed to speak in front of others }\end{array}$ & 55 & 30.2 & 22 & 12 & 36 & 19.7 & 21 & 11.5 & 30 & 16.4 \\
\hline 7. & $\begin{array}{l}\text { Large class size and fixed sitting arrangements } \\
\text { are not convenient to do oral interaction. }\end{array}$ & 118 & 64.8 & 6 & 3.2 & 5 & 2.7 & 10 & 5.4 & 8 & 4.3 \\
\hline 8. & $\begin{array}{l}\text { I prefer to use my L1 during pair or group } \\
\text { interaction }\end{array}$ & 132 & 72.5 & 30 & 16.4 & 10 & 5.4 & 5.4 & 2.7 & 5 & 2.7 \\
\hline 9. & $\begin{array}{l}\text { I understand the teacher better when he/she uses } \\
\text { my L1 most dominantly. }\end{array}$ & 82 & 45 & 60 & 33 & 30 & 16.4 & 10 & 5.4 & - & - \\
\hline 10. & $\begin{array}{l}\text { I make great effort to interact with my friends in the } \\
\text { classroom. }\end{array}$ & 10 & 5.4 & 148 & 81.3 & 12 & 6.5 & 12 & 6.5 & - & - \\
\hline
\end{tabular}

As can be seen from table 2, all points (Items 1-10) talk about challenges that students face during oral interaction in EFL classroom. The first item talks about students self confidence during oral interaction, which says "I often feel shy and fearful to speak in English even with my friends". Regarding this item, $50.5 \%$ and $32.9 \%$ of the students replied that they strongly agree and agree respectively. Similarly, the observation result revealed that students were never willing to express their own ideas and feelings freely during oral activities. Also during the interviews made with English language teachers, T1, T2and T3 responded that their students are not keen to articulate their own ideas and feelings unreservedly during oral activities. From this data, we can infer that students are not confident enough to participate in oral interaction activities. The reason behind this unwillingness may be the issue to be seen later on in this section.

The point in item 2 is about students' preferences i.e., whether they prefer to learn grammar and vocabulary rather than practicing the target language genuinely during oral interactions saying, "I prefer grammar and vocabulary practice than oral interaction" out of which $56 \%$ and 27.4 of the students replied that they strongly agree and agree respectively. This point is also proved during the interview sessions that students prefer to learn grammar and vocabulary than plunging themselves into real and authentic oral interaction. For example, T1, T3, $\mathrm{T} 4$ and $\mathrm{T} 5$ responded that students are interested to learn grammar and vocabulary rather than oral interaction. But T2 responded that the students are less interested for grammar and vocabulary learning itself, too.

Item 3 which talks about whether a major portion of class time is taken up by teachers talk or not, $72.6 \%$ and $27.4 \%$ of the students responded that they strongly agree and agree respectively. Likewise, the data from the observed classes show that the major portion of class time is frequently taken by English language teachers. Also the interview result revealed that teachers talk a lot because students are not willing to talk. For example, T1 responded that he tried to manage the class time using student-centered approach but no student could speak or say something even if the teacher does his best. So, he considered that the only resolution for this is changing the state of affairs to teacher-centered situation.

Not only this, T2 and T3 also replied that they first give chance for students to speak but when learners prefer silence, they indicated that turning to the teacher 
Zeleke Teshome Lucha \& Alemtsehay Berhanu

centered situation became the option, and the other teachers responded the same thing. This indirectly implies that a teacher centered/dominated classroom situation is being employed. This problem is mainly from the English language teachers' side as they have got the upper hand to manage the classroom, to render opportunity for students whatever the rate of motivation may be. However, as the data indicated, the teachers use the larger portion of the time allotted for the session by using their authority or asymmetrical relationship of students and the teacher.

Concerning item 4 which reads, "I feel discouraged to participate when the teacher interrupts us to correct our oral errors during our interactions", $67 \%$ and $20 \%$ of the students strongly agree and agree respectively that they feel unenthusiastic to participate again when the teacher interrupts them to correct their oral errors. Correspondingly, the observation and interview results also revealed that students hate their teachers' interruptions during oral communication sessions. However, the teachers' belief about error correction is not as to the modern view of language teaching and learning theory.

On the subject of item 5 which says "The time given to do oral interaction activities is insufficient", $5.4 \%$ and $81.3 \%$ of the students responded that they strongly agree and agree respectively. Also the observation and interview result revealed that the time given to carry out oral interaction activities is not sufficient because of the large number of students in the class and fixed (unconducive) sitting arrangement. This implies that the time is inadequate because of large class size.

Concerning item 6 which puts "I am not willing to talk freely in the class as I was not accustomed to speak in front of my classmates", $30.2 \%$ and $22 \%$ of them responded strongly agree and agree respectively. On other hand, $19.7 \%$ of them replied "disagree" whereas $11.5 \%$ of them answered saying "strongly disagree" and 16.4 of them "have no idea". The indication was that students did not develop the habit of freely interacting in EFL classrooms previously which could have helped them as stepping stones for the present language learning in actual language classes.

The observation result also revealed that students were rarely interested to speak in English freely in the class as well as the interview result shows that students were unwilling because they were not familiarized to speak it before.

Concerning item 7 of the same table, large class size and fixed sitting arrangements were hindering learners' oral interaction using the target language. From the total selected students, $64.8 \%$ and $3.2 \%$ of the students responded that they strongly agree and agree respectively. In the same way, the observation and interview result revealed that large class size and fixed sitting arrangement too hindered the classroom interaction. For example, during an interview held with EFL teachers, T1, T2, T4 and T5 replied that large class size and fixed sitting arrangements were the main hindering factors of the classroom oral interaction pointed out by teacher-interviewees, and they said that it is difficult to give chances for each student during discussion in the classroom. What's more, T3 responded that there is
Sci. Technol. Arts Res. J., April-June 2015, 4(2): 294-301

mismatch between the given time and class size so it is very difficult to implement the oral interaction in large class size.

On item 8 which says, "I prefer to use my L1 during pair or group interaction", $72.5 \%$ and $16.4 \%$ of the students responded that they strongly agree and agree respectively. Besides, during the classroom observation sessions, students were frequently observed using their first language during oral interaction activities, and the interview result also revealed the same thing which is a great challenge in EFL speaking class. For example, T1and T4 replied that most of the time, students prefer to use their first language during pair or group work even if they tell them and order them not to use their first language. As to the data obtained from these two language teachers, when they round on the groups, students keep silent rather than discussing in English, when they ask them why they don't discuss most students replied that they did not have the courage to speak in English.

On item 9 of the same table puts forward as, "I understand the teacher better when he/she uses my $L 1$ most dominantly" 45 and $33 \%$ of the students responded saying strongly agree and agree on the idea. Correspondingly, the observation and interview result too revealed that students understand their daily lesson better when the teachers use their first language most dominantly during oral interaction. The interviews made with T1 and T4 also uncovered the fact that students understand them better when they put in between the phrases through the students' mother tongue during oral interaction.

But from second or foreign language teaching/ learning theory point of view, language teachers should not use students' first language most of the time but should use when it is needed to clarify things more. However, some of the teachers replied that they don't let their students to speak in their first language thinking that if they are given chances to regularly use their first language, they always incline to dominantly use it during class interaction which affects the improvement of their target language.

Regarding item 10 which says, "I make great effort to interact with my classmates in the classroom", $81.3 \%$ of the students shown their agreement. But the observation and interview result shows that students never make great effort to interact.

To put it in nut shell, the challenges that student face during oral interaction in EFL classroom were: large class size, shortage of time for oral interaction activities/ sessions, shortage of supplementary teaching materials that boost their oral skills, prior students' unfamiliarity with oral interactions, lack of vocabulary, the cumbersome seating arrangement, students' L1 interference, and students' lack of confidence i.e. students feel shy and fear to interact using English language.

\section{Teachers Use of different Activities during Oral Interaction in EFL Class}

Presentation and analysis of data obtained through questionnaire, observation and interview on teacher's use of different activities during oral interaction in EFL class are presented here under. The keys used to represent the scale in table 3 are similar with that of tables 1 and 2 . 
Table 3: Teachers' use of different activities during oral interaction in EFL classroom

\begin{tabular}{|c|c|c|c|c|c|c|c|c|c|c|c|}
\hline \multirow{2}{*}{ No } & \multirow{2}{*}{ Statement/s } & \multicolumn{2}{|c|}{1} & \multicolumn{2}{|c|}{2} & \multicolumn{2}{|c|}{3} & \multicolumn{2}{|c|}{4} & \multicolumn{2}{|c|}{5} \\
\hline & & No & $\%$ & No & $\%$ & No & $\%$ & No & $\%$ & No & $\%$ \\
\hline 1. & $\begin{array}{l}\text { Teachers use a variety of interaction activities } \\
\text { suggested in the text during speaking lesson. }\end{array}$ & - & - & - & - & 150 & 82.4 & 12 & 6.5 & 10 & 5.4 \\
\hline 2. & $\begin{array}{l}\text { Teachers employ a variety of interaction } \\
\text { activities outside the text book. } \\
\text { My interest to participate in the class become }\end{array}$ & - & - & - & - & 25 & 13.7 & 157 & 86.2 & - & - \\
\hline 3. & $\begin{array}{l}\text { less when the oral interaction activities are } \\
\text { difficult. }\end{array}$ & 92 & 50.5 & 40 & 22 & 16 & 8.7 & 14 & 7.6 & 20 & 11 \\
\hline 4. & $\begin{array}{l}\text { I don't like the interaction activities that are } \\
\text { suggested in the text book. }\end{array}$ & 22 & 12 & 18 & 9.8 & 50 & 27.4 & 50 & 27.4 & 42 & 23 \\
\hline 5. & I like teacher fronted oral activities most often. & 111 & 61 & 56 & 30.7 & 8 & 4.3 & 7 & 3.8 & - & - \\
\hline 6. & $\begin{array}{l}\text { I am interested to participate in the class when } \\
\text { the oral interaction activities are too easy. }\end{array}$ & 24 & 13.1 & 32 & 17.1 & 49 & 26.9 & 47 & 25.8 & 30 & 16.4 \\
\hline
\end{tabular}

Basically, items $1-6$ in table 3 are concerned with EFL teachers use of different oral interaction activities. For instance, item 1 rises whether "Teachers use a variety of interaction activities suggested in the text during speaking lesson" or not. Here, $82.4 \%$ of the students responded that they disagreed that their EFL teachers did use the interactional activities already incorporated in their teaching books. Similarly, the observation result revealed that teachers rarely use varieties of interactional activities suggested in the text book during speaking lesson. Also the result obtained from the interview made with teachers shows that teachers endeavor to apply but don't use the suggested oral activities due to shortage of time, students' lack of interest and classroom condition. For instance, T1 and T5 replied that they try their level best to use interactional activities suggested in the text during speaking lesson, but their students are unwilling to do so. Because of this, they replied preferring to tell them the highlight of it and jump over to other content of the daily lesson.

On top of this, T2, T3 and T4 too replied that their students are not willing to participate in oral interaction activities. So rather than wasting their time, they replied moving to the next portion and teach other language skills. This implies that teachers themselves don't boldly encourage students to use variety of interactional activities suggested in the text well during speaking lesson.

Item 2 asks whether "Teachers employ a variety of interaction activities outside the text book" or not. From the total selected student populations, $13.7 \%$ of them responded that they disagree and $86.2 \%$ of them responded that they strongly disagree. On the same way, the observation result revealed that teachers never employed variety of interactional activities outside the text book. Also during the interviews conducted the EFL teachers explained that it is really difficult for them to say they use varieties of interactional activities and they forwarded that they did not use variety of interaction activities because of different factors. Some of the factors include: class size, shortage of time and others. So, they mostly use teacher fronted approach in their EFL classes. This implies that teachers did not play what is expected of them and they were less committed to help their students during oral interaction sessions.

For item 3 which says "My interest to participate in the class becomes less when the oral interaction activities are difficult', $50.5 \%$ and $22 \%$ of the students replied that they strongly agree and agree respectively. Whereas, $11 \%$ of the students responded that they have no idea.

However, the observation result revealed that students were never willing to participate in interaction class whether the activities are easy or difficult. The interview result also showed the same thing. For example, T2, T3 andT5 responded that except some active students other students are reluctant to participate in oral interaction classes whether the activities are easy or difficult. But T2 and T4 replied that sometimes some students are willing to participate when the oral interaction activities are easy. This implies that even if the interaction activities are easy students were not interested to participate in oral interaction activities in EFL speaking classroom except very few of them.

On item no 4 which says, "I don't like the interaction activities that are suggested in the text book", $12 \%$ of the students responded that they strongly agree, $9.8 \%$ of them agree, 27.4 of them disagree, $27.4 \%$ of them strongly disagree and $23 \%$ of them have no idea. The observation and interview result revealed that students don't like not only the activities suggested on their text book but also any type of interaction activities. For example, from the interviews held with T2, T3 and T5 it was obtained that whenever they teach oral interaction activities on their text book students simply keep silent and look at them. This shows that students don't like the interactional activities suggested on their text books.

Concerning item 5 which says, "I like teacher fronted oral activities most often", $61 \%$ and $30.7 \%$ of the students replied that they strongly agree and agree respectively. Similarly, the observation result also revealed that students mostly and silently attended teacher fronted oral presentations. But the interviewed teachers indicated that some of their students prefer oral interaction among each other. This implies that if EFL teachers make the teaching environment conducive, students may get the opportunities to interact orally in the classroom which finally helps them boost their speaking skills.

To sum up, the practices of oral interaction activities in EFL speaking class is less than the required target. This indicates that EFL teachers themselves did not play the roles expected of them as well as they lack commitment for their work. On another hand, the students themselves also did not play their own share. Not only this, the 
Zeleke Teshome Lucha \& Alemtsehay Berhanu

general classroom conditions are also affecting the use of different interaction activities in EFL classroom.

\section{CONCLUSIONS}

The aim of this thesis was to study on students' implementation of classroom oral interaction in Sire Secondary School EFL class. The finding revealed that the support of English language teachers to foster interaction class is below the required target. And the result clearly showed that teachers and only active students dominate the class interaction. So teachers do not provide help for students to foster classroom interaction rather they use teacher centered approach.

The study also revealed that there are challenges that students face during classroom oral interaction. The challenges include: students' lack of interest to participate in oral interaction in EFL speaking classroom, their lack of the necessary language skills, lack of teachers' commitment, mother tongue interference, classroom condition; such as large class size and fixed seating arrangements and others are some of the challenge that students face during oral interaction activities in EFL speaking classroom.

Moreover, the analysis of data indicates that EFL teachers' don't use different interaction activities that help to foster the realization of students' classroom oral interaction in EFL speaking class. The overall result revealed that they rarely use different interaction activities to foster classroom interaction.

Finally, Classroom oral interaction is not implemented properly in EFL speaking class of the selected school. Teachers and students did not play effective roles in implementation of students' classroom oral interaction. Teachers, for instance, were observed playing very few roles in helping, encouraging, facilitating students to interact.

\section{Conflict of Interest}

Authors declared no conflict of interest.

\section{Acknowledgements}

In this study, we can never make it alone. We have a string of people to whom to express our gratitude for their support. The first person without whom we would never have come this far with this paper are teachers and students of Sire Secondary School who scarified their precious time in filling the questionnaires and answering the interview questions for the main study. Special thanks should go to the co-observer teachers Daba Marga and Lamesa Oli who helped us during class observations by scarifying their precious time. We would like to extend our respectful thanks to all the school members those helped us during this study.
Sci. Technol. Arts Res. J., April-June 2015, 4(2): 294-301

\section{REFERENCES}

Beale, J. (2007). Assessing interactive oral skills in EFL context. Retrieved March $9^{\text {th }}$, 2008 from: http://www.jasonbeale.com/essay pages/assessment.htm/

Berhanu Bogale (2000). Verbal interaction in group work. (Unpublished Ph. D thesis) Addis Ababa University, Addis Ababa, Ethiopia.

Bygate, M. (1987). Speaking. Oxford: Oxford University Press.

Elizabeth Ayalew (2003). Faculty Gender and Classroom Interaction in EFL classes. The Ethiopian Journal of Education XX III (2).

Ellis, R. (1990). The study of second language Acquisition. Oxford: Oxford University Press.

Fassinger, R.E. (1995). From Invisibility to Integration: Lesbian Indentify in the workplace, in the career Development. Quarterly 44(2).

Harmer, J. (1983). The practice of English language teaching Longman Handbooks for Language Teachers. $3^{\text {rd }}$ edition, Longman.

Liu, J. (2001). Asian students' classroom communication patterns in U.S. Universities: An Emic perspective. West port, CT, USA: Greenwood publishing Group, Inc.

Long, M.H. and Porter, P.A. (1984). Group work, inter language talk, and second language acquisition. TESOL Quarterly 19(2): 207-226.

Melku Tezera. (2005). Implications of classroom interaction with reference to oral communicative focused tasks. (Unpublished M.A thesis) Addis Ababa University.

Meseret Gizachew (2007). Classroom interactional implication in teaching oral communication through the use of tasks. (Unpublished M.A thesis) Addis Ababa University.

MOE (2003). A National Curriculum Guideline for Preserving Teacher Education Programs (Unpublished).

Moges Abay (2007). The assessment of Techniques Practiced by EFL Teachers in implementing active learning. Upper primary schools Gonder Town in focus: M.A. Thesis Addis Ababa University (Unpublished).

Nunan, D. (1992). Research methods in language learning Cambridge: Cambridge University Press.

Rivers, W.M. (1983). Speaking in many languages. Cambridge: Cambridge University Press.

Rivers, W.M. (Ed.) (1987). Interactive Language Teaching. New York: Cambridge University Press.

Sisay Asefie. (1999). Classroom Interaction and Its Influence on the development of students speaking skill in English. M.A. Thesis, Addis Ababa University. (Unpublished).

Tamene Kitila. (2000). Classroom Verbal Behavior and Learning Opportunities in Selected Secondary School EFL Classroom. (Unpublished Ph. D thesis) Addis Ababa University.

Tsui, A.B.M. (1985). Introducing classroom interaction London: Penguin Books Ltd. 